NASA Technical Memorandum 83717

\title{
Interaction of Sulfuric Acid Corrosion and Mechanical Wear of Iron
}

George W. P. Rengstorff

The University of Toledo

Toledo, Ohio

and

Kazuhisa Miyoshi and Donald H. Buckley

Lewis Research Center

Cleveland, Ohio

Prepared for the

Joint Lubication Conference

cosponsored by the American Society of Mechanical Engineers and the American Society of Lubrication Engineers

San Diego, California, October 22-24, 1984 


\section{INTERACTION OF SULFURIC ACID CORROSION ANO \\ MECHANICAL WEAR OF IRON}

George W. P. Rengstorff

The University of Toledo

Toledo, Oh10 43606

Kazuhisa Miyoshi* and Donald H. Buckley ${ }^{+}$

National Aeronautics and Space Administration

Lewts Research Center

Cleveland, Oh10 44135

\section{ABSTRACT}

Friction and wear experiments were conducted with elemental iron sliding $i$

on aluminum oxide in aerated sulfuric acid at concentrations ranging from very dliute $\left(7 \times 10^{-5} \mathrm{~N} ; 1 . e ., 4 \mathrm{ppm}\right)$ to very concentrated (96 percent acid). Load and reciprocating sliding speed were kept constant. With the most dilute acid concentration of $7 \times 10^{-5}$ to $2 \times 10^{-4} \mathrm{~N}$, a complex corrosion product formed that was friable and often increased friction and wear. At silghtly higher concentrations of $0.001 \mathrm{~N}$, metal losses were essentially by wear alone. Because no buildup of corrosion products occurred, this acid concentration became the standard from which to separate metal loss from direct corrosion and mechanical wear losses. When the acid concentration was increased to 5 percent $(1 \mathrm{~N})$, the well-established high corrosion rate of iron in sulfuric acid strongly dominated the total wear loss. This strong corrosion increased to 30 percent acid and decreased somewhat to 50 percent acid in accordance with expectations. However, the low corrosion of iron expected at acid concentrations of 65 to 96 percent was not observed in the wear area. It was apparent that the normal passivating film was being worn away and a galvanic cell

\footnotetext{
* Member ASLE.

+Fellow ASLE.
} 
established that rapidly attacked the wear area. Under the conditions where direct corrosion losses were highest, the coefficient of friction was the lowest.

\section{INTROOUCTION}

Corrosion has been recognized as an important variable in the friction and wear of metals (1). St11l, its role is not well understood. Most studies have been concerned with specific practical problems, such as the use of anticorrosion additives in lubricants (2) or moving parts in body implants (3). However, general basic knowledge is missing.

The effects of corrosion are complex. There can be a general attack of surfaces with no particular effect in the wear region. However, the wear contact region differs electrochemically from the surroundings. It contains metal that is cold worked, that is being highly stressed elastically as well as plastically, and that is at locally high temperatures at shearing asperities $(4,5)$.

A most important fact is that mechanical wear and corrosion both depend on surface deposits and films. This leads to at least four different interaction phenomena between wear and corrosion. In one, a tenacious, low-friction film can form that resists corrosion losses while lowering mechanical wear losses $(6,7)$. Under other conditions, a thick; friable deposit forms that has high friction and increases mechanically induced wear losses (8). Under a third set of conditions, the mechanical action wears away flims that protect against corrosion. This leads to locally high corrosion in. the wear area that is enhanced by galvanic coupling with the surrounding regions (8). This has been observed with nickel as well as iron (9). Laștly, there are conditions where it is apparent that, in iron, corrosion losses are simply added to mechanical wear losses (8). 


\section{MATERIALS}

The iron (better than 99.99 percent pure) was annealed to a hardness of 30 to 35 Rockwell B after machining. The sulfuric acid was ACS reagent-grade concentrated acid, which is specified to be 95.5 to 96.5 percent by weight. The water used to make the solutions was defonized, distilled, and saturated with room temperature air.

\section{APPARATUS}

The bullet-shaped, 6.4-mm-diameter iron riders used had a tip radius of $3.2 \mathrm{~mm}$ and were $16 \mathrm{~mm}$ long overall. They were mounted in a holder and were sild over flats of aluminum oxide (sapphire). These experiments differed from previously reported research $(6,7)$, in which a sapphire ball rider was moved over a flat metal specimen.

The friction apparatus is shown schematically in Fig. 1. The aluminum oxide flats were attached to the bottom of glass or polytetrafluoroethylene (PTFE) cups. In operation, the cups were filled with the acid solution to about $3 \mathrm{~mm}$ above the surface of the flats. The cups were held in a vise and reciprocated under the metal slider during an experiment.

Epoxy cement was used to attach the flats to the inside bottom of the glass cups, which had an inside diameter of $30 \mathrm{~mm}$ and a height of $16 \mathrm{~mm}$. For the 96 percent acid solution a similar cup was made of PTFE. A groove was cut into the inside bottom of the PTFE cup, and the flat was fitted tightiy in the groove so that a cement was not needed.

The flats were cut from smooth, very dense (transparent) sapphire sheets. However, the initial sheets had been used in earlier friction studies and had a few widely spaced scratches. In this work, care was taken to not have the slider cross any of these scratches. Also, silding was carried out on many different paths on the several flats used. In any case, the soft rounded iron sliders did not visibly groove the flats. 
As indicated in Fig. I the mounted flats were moved back and forth under the loaded iron rider. The motion of the flats was $1 \mathrm{~cm}$ in each direction. The wear motion was variable and shorter because of the friction drag. The rider load was $2.5 \mathrm{~N}(250 \mathrm{~g})$. The arm holding the rider was flexible, so the friction force could be measured with calibrated strain gages and continuousiy recorded. There were nine reversals per minute, that is, the aluminum oxide flat traveled at an average speed of $9 \mathrm{~cm} / \mathrm{m} 1 \mathrm{n}$. Each experiment lasted $60 \mathrm{~min}$. Thus the rider passed over the flat 540 times ( 270 times each way) during an experiment. The experiments were done in air, so the acid was standardized in the aerated condition.

\section{EXPERIMENTAL PROCEDURE}

The hemispherical tips of the iron riders were polished with 6- and 3-um diamond paste. Finish polishing was with a wet metallographic polishing cloth impregnated with $0.3-\mu m$ a-aluminum oxide. The specimen was rotated in a small lathe for the polishing operation and washed afterwards.

The aluminum oxide flats in their cups were clamped in the jig. The specimens (the riders) in their holders were lowered to a few millimeters above the flats, and alignments were checked. Then the acid was dropped into the cups to cover the flats to the proper depth. Thereafter the specimen tips were lowered until they just touched the flats, the load was installed, and the experiment was started.

The friction force of the rider moving across the flat was determined by strain gages on. the flexible arm that held the loaded rider. The output from the calibrated strain gages was recorded continuousiy. The coefficient of friction then was the force divided by the load of the rider. The static coefficient $\mu_{s}$ was the maximum friction force in each direction of travel or, as used, half the maximum force in a complete reversal of travel. The kinetic coefficient $\mu_{k}$ was estimated in the usual manner by using a force 
that was the mean between the maximum force (stick) and the minimum force (s11p) when stick-silp occurred.

The amount of metal lost in wear was determined by measuring the size of the wear area on the tip after an experiment. The maximum length of the wear area, which occurred in the direction of motion, and its width were measured on a photographic print. Then the amount of metal that would have been removed from a circular area of an average diameter was calculated as $10^{-5} \mathrm{~mm}^{3}$ and used to one, or at most, two significant figures.

ESTIMATION OF DIRECT CORROSION CONTRIBUTION TO METAL LOSS IN WEAR

To achieve an insight into the interaction of mechanical wear and corrosion, it is desirable to separate metal losses from the two effects. When the direct corrosion loss is great enough, it is possible to estimate corrosion rates in the wear area. Comparison with published corrosion rates and a comparison of the corrosion pattern in the wear zone with the pattern outside the wear zone provide some insight into the contribution of corrosion to total wear loss.

The basic procedure for estimating corrosion rates in the wear zone was as follows:

(1) As a base, the wear area dlameter was used to calculate the volume of metal lost under conditions where the corrosive solution did not directly cause the corrosion loss. For fron this base was the diameter of $0.23 \mathrm{~mm}$ and total loss of $5 \times 10^{-5} \mathrm{~mm}^{3}$ obtained with $0.001 \mathrm{~N}$ sulfuric acid.

(2) The total volume of metal lost due to the combined normal friction and corrosion was measured for each experimental condition. The volume lost under the base condition was subtracted from this to give the volume lost by corrosion.

An important limitation. of the procedure are the errors in metal losses introduced by the irregular shape of the wear area. Another limitation of the 
estimation process is its inability to detect low corrosion rates. A corrosion rate of over $5 \mathrm{~mm} / \mathrm{yr}$ is considered unacceptable for iron- or nickel-base alloys (10). Yet this rate would only change the dlameter of a $0.23-\mathrm{mm}$ wear area to $0.25 \mathrm{~mm}$, both of which are within the observable scatter band. A rate of 7 $\mathrm{mm} / \mathrm{yr}$ was therefore used as the detection limit.

\section{RESULTS AND DISCUSSION}

The corrosion of fron in neutral $(\mathrm{pH}=7)$, slightly acidic, or slightly basic water is complex. Corrosion reaction products form on the surface, or are deposited on the surface, that are recognized as a mixture of divalent and trivalent hydroxides, oxyhydroxides, and oxides (10-14). There is also X-ray photoelectron spectroscopic (XPS) evidence that iron sulfate may be part of the bullt-up layer (6).

Iron usually corrodes rapidiy in nonoxidizing acids. However, if the oxidation is strong enough, the iron surface may become passivated by a protective oxide layer. Iron's behavior in sulfuric acid is consistent with this generality. Steel drums can be used for storing 60 to 98 percent sulfuric acid at room temperature. In fact, the well-documented corrosion rates of three concentrations in the range used in this research are shown in table $1(10)$. Below about 60 percent sulfuric acid the corrosion rates are so high that the use of steel in contact with the acid is impractical. The published results of one laboratory study show that the corrosion rates at 25 and 50 percent sulfuric acid are over a thousand times that at 75 percent acid (13).

The passivating film is probably $\mathrm{Fe}_{2} \mathrm{O}_{3}$. However, $\mathrm{Fe}_{2} \mathrm{O}_{3}$ is soluble below a pH of about 2 . or 3 , which occurs at about 0.01 to $0.001: N$. In dilute solutions, $\mathrm{pH}$ is an inverse function of hydrogen ion concentration, so increasingly low or negative $\mathrm{pH}$ is associated with sulfuric acid up to about 30 percent acid. At higher concentrations the hydrogen ion concentration decreases, so $\mathrm{pH}$ increases again. At some high concentrations (60 to 96 percent) the $\mathrm{pH}$ is high 
enough so that a $\mathrm{Fe}_{2} \mathrm{O}_{3}$ fllm continuous enough to passivate fron would not readily dissolve.

\section{WEAR IN DILUTE SULFURIC ACID}

A notable result of friction and wear tests of iron tips operating in sulfuric acid at concentrations of $1.0 \mathrm{~N}$ ( 5 percent) or less (fig. 2) was that friction and wear were highly variable in the very dilute sulfuric acid range $7 \times 10^{-5}$ to $2 \times 10^{-4} \mathrm{~N}\left(4\right.$ to $12 \mathrm{ppm}$ ). When a specimen was operated at $10^{-4} \mathrm{~N}$, a high static coefficient of friction $\left(\mu_{s}=0.51\right)$ was observed and wear loss was high (fig. 3(a)). A thick oxidation product formed in the wear area, which then cracked extensively (Fig. 3(b)). Some of this deposit broke away from the wear area and appeared as wear debris. In a high-magnification SEM photograph of a portion of the wear area that is extensively cracked ( $\mathrm{Fg} .3(\mathrm{c})$ ) the structure in the cracked corrosion product is observable.

On this and similar specimens a complex surface deposit formed that consisted of iron hydroxides, iron oxides, iron oxyhydroxides, and perhaps iron sulfate, as mentioned earlier. This deposit was weak and friable and was not a protective, passivating film. Friction loading caused it to crack. In those regions where the deposit was thickest, cracking was so bad that the friction was ralsed and metal loss increased. However, a specimen operated at the same acid concentration but with lower friction $\left(\mu_{s}=0.31\right)$ and showing less wear was similar in appearance except that the cracks were fewer and more localized. This is consistent with the lower friction and wear loss. Note that the buildup of the corrosion product was not 11 imited to the wear area (Fig. $3(c))$. It also occurred well outside the wear area (Fig. $3(d))$, but not as thickly as it did inside.

An iron tip operated in $0.001 \mathrm{~N}$ (0.005 percent) sulfuric acid showed little evidence of corrosion product bulldup on the wear area or outside it 
(Fig. 4). Because of the small amount of wear and the general pattern of corrosion and wear, the volume of metal lost and the stze of this wear area were taken as the base conditions for estimating how direct corrosion contributed to the removal of metal during wear. The direct corrosion losses as determined by these calculations are given in Table 2. There are no calculations for acid concentrations below $0.001 \mathrm{~N}$. The formation of corrosion products on the surface and their effect on friction and wear mask the effects from direct removal of metal by corrosion.

In 0.01 and $0.1 \mathrm{~N}(0.05$ and 0.5 percent) acid the total wear loss was small (Fig. 2). Table 2 indicates that the contribution of direct corrosion to this loss was below the detection level of $7 \mathrm{~mm} / \mathrm{yr}$. The SEM micrographs reveal grain boundary etching outside the wear area in $0.1 \mathrm{~N}$ acid.

In $1.0 \mathrm{~N}$ ( 5 percent) acid the surface of the wear area was generally smooth, although the appearance varied somewhat across the area. Outside the wear area the grain boundaries were rather deeply etched, but no deposition products were apparent (Fig. 5). The estimated corrosion rate was much higher at 5 percent $(1.0 \mathrm{~N}) \mathrm{H}_{2} \mathrm{SO}_{4}$. It was high enough to materially add to the metal lost by mechanical friction effects. In fact, the estimated rate of 27 $\mathrm{mm} / \mathrm{yr}$ is close to the $30 \mathrm{~mm} / \mathrm{yr}$ reported in the literature (13). This led to the conclusion that the corrosion loss in the wear area was nearly the same as the overall corrosion loss. There does not appear to be a strong galvanic cell between the wear area and its surroundings.

\section{SURFACE STRUCTURES OF IRON WEAR IN CONCENTRATEO SULFURIC ACID}

The friction and wear of iron were measured after it had operated in 30 , 50, 65, 75, and 96 percent sulfuric acid (Fig. 6). For comparison the data point for iron after it had operated in 5 percent $(1.0 \mathrm{~N})$ acid is repeated from Fig. 2. The wear increased sharply from the value at 5 percent acid to a maximum at 30 percent acid and then dropped sharply to 50 percent acid. It 
dropped a little lower to 65 percent acid, but not to the very low value that was expected from the known low conversion rate. Wear loss was a little higher at 75 percent acid and was much higher at 96 percent acid.

Over this composition range of 5 to 96 percent $\mathrm{H}_{2} \mathrm{SO}_{4}$, the static coefficlent of friction $\mu_{s}$ ranged between 0.28 and 0.18 . There was no clear pattern to the variations, except that the highest corrosion rate was accompanied by the lowest $\mu_{s}$. Stick-slip increased markedly at the higher acid concentrations. Thus, Fig. 6 indicates greater differences between $\mu_{s}$ and $\mu_{k}$ than does Fig. 2 , the plot for more dilute acids.

After operation of the 1ron rider in 30 percent acid, grain-boundary etching occurred even in the wear area (Fig. $7(b)$ ), where cold deformation tends to smear the surface. Still, corrosion did not produce faceted corrosion patterns as in the wear areas of nickel corroded under similar conditions (9). However, the iron surface outside the wear area indicates (Fig. $7(\mathrm{c})$ ) a faceted, rapid corrosion pattern. The estimated corrosion rate (Table 2) in the wear area of $93 \mathrm{~mm} / \mathrm{yr}$ is less than the published value of $220 \mathrm{~mm} / \mathrm{yr}$ given in the literature (13). This, plus the structure comparison between the regions inside and outside the wear area, led to the conclusion that the wear area was not anodic to its surroundings. It is probable that the large loss in the wear test was almost entirely the result of the high overall corrosion rate of iron in 30 percent sulfuric acid.

The estimated corrosion rate at the wear area for 50 percent acid was $43 \mathrm{~mm} / \mathrm{yr}$. This was one-third the published corrosion rate of $125 \mathrm{~mm} / \mathrm{yr}$ for Iron (13). The difference may be due to a bulidup of a limited protective coating on the iron grains in some orientations. It is clear that the corroston enhancement of wear loss was not due to the wear area becoming anodic to its surroundings. The appearance of the wear area and its surroundings was very much like that in Fig. 7 . 
The Iron tip worn in 65 percent acid appeared similar to the tip worn in 75 percent acid. They both were similar to Fig. 7, although corroded much less deeply.

A phenomenon that was especially notable for the tips worn in 96 percent acid, as well as in 65 and 75 percent acid, was the high corrosion losses. The corrosion rates were much higher than the well-known low rates of steel in the same acids without simultaneous wear. Table 2 gives the estimated corrosion contribution to wear loss as $25 \mathrm{~mm} / \mathrm{yr}$ for 65 percent acid, $27 \mathrm{~mm} / \mathrm{yr}$ for $75 \mathrm{per}$ cent acid, and $57 \mathrm{~mm} / \mathrm{yr}$ for 95 percent acid. This compares with the rates of less than $1 \mathrm{~mm} / \mathrm{yr}$ discussed earlier $(10)$. This must mean that the passivating layer was being worn away in the wear area, making the wear area anodic with respect to its surroundings. Of course, it is possible that the rapid corrosion in the wear area was due directly to wearing away a passivating film. However, general knowledge of corrosion behavior strongly suggests the additional effect of forming a galvanic cell between the wear area and its surroundings.

\section{CONCLUSIONS}

The experimental data for loss of iron silding on aluminum oxide in aerated sulfuric acid with concentrations ranging from very dilute to very concentrated have been presented. The conclusions derived from differences in the behavior of iron in various acid concentration ranges are as follows:

1. At the very dilute acid concentrations of $7 \times 10^{-5}$ to $2 \times 10^{-4} \mathrm{~N}$ (4 to 12 ppm) corrosion produced a soft, friable deposit on iron. Breakup of this hydroxide-oxide-oxyhydroxide-sulfate deposit gave erratic and often high loss of iron in the wear area.

2. At somewhat higher sulfuric acid concentrations $(0.001$ to $0.1 \mathrm{~N})$, the loss of metal in the wear area was at a minimum, and there was no butldup of corrosion products. 
3. At 5 percent $(1.0 \mathrm{~N})$ and 30 percent actd the well-known high loss of Iron due to corrosion dominated the overall loss of iron in the wear area. This effect dropped at 50 percent ac1d, but direct corrosion loss was still dominant over loss due to sliding effects.

4. It was expected that at 65 to 98 percent sulfuric acid loss of metal due directly to corrosion in the wear region would be low. It was not. It was concluded that friction and mechanical wear removed the passivating coating that protects iron from corrosion in concentrated sulfuric acid. Thus a galvanic cell was established between the wear area and its surroundings that greatly increased the loss of fron in the wear area.

5. A correlation between coefficient of friction and acid concentration was not particularly clear. However, the following general observations were made :

a. At the very low sulfuric acid concentrations where a friable corrosion product developed on the iron, those specimens having unusually high friction coefficients also had high metal loss in wear.

b. Over the entire acid concentration range the highest direct corrosion loss was associated with the lowest coefficients of friction.

c. At acid concentrations of 5 percent $(1.0 \mathrm{~N})$ and below, little or no stick-silp occurred. On the other hand, at acid; concentrations of 30 percent and higher, the static coefficient of friction $\mu_{s}$ was consistently appreciably nigher than the kinetic $\mu_{k}$.

\section{REFERENCES}

1. Eyre, T. S., "Wear Characteristics of Metals," Source Book on Wear Control Technology. American Society for Metals, Metals Park, Ohio, D. A. Rigney and W. A. Glaeser, eds., 1978, PD. 1-10. 
2. Neale, M. J., ed., Tribology Handbook, Butterworths (London), 1973. (Section on lubricants.)

3. Waterhouse, R. B., "Fretting in Hostlle Environments," Source Book on Wear Control Technology, American Socfety for Metals, Metals Park, Ohio, D. A. Rigney and W. A. Glaeser, eds., 1978, Pp. 261-269. (Originally presented at the 3rd Tribology Conference, Tribology for the Eighties, Paisley, Scotland, Sept. 22-25, 1975.)

4. Bowden, F. P., and Tabor, D., The Friction and Lubrication of Solids, Clarendon Press (Oxford), 1950. (With corrections through 1971.)

5. Rabinowicz, E., Friction and Wear of Materials. Wiley, New York, 1965.

6. Rengstorff, G. W. P., Miyoshi, K., and Buckley, D. H., "Friction and Wear of Iron in Corrosive Media," NASA TP-1985, 1982.

7. Rengstorff, G. W. P., Miyosh1, K., and Buckley, D. H., "Friction and Wear of Iron and Nickel in Sodium Hydroxide Solutions," ASLE Transactions. Vol. 26, No. 4, Oct. 1983, pp. 509-516.

8. Rengstorff, G. W. P., Miyoshi, K., and Buckley, D. H., "Friction and Wear of Iron in Sulfuric Acid," NASA TP-2289, 1984.

9. Rengstorff, G. W. P., Miyosh1, K., and Buckley, D. H.; "Friction and Wear of Nickel in Sulfuric ACid", NASA TP-2290, 1984.

10. Fontana, M. G., and Greene, N. D., Corrosion Engineering, 2nd ed., McGrawH111, New York, 1978.

11. Uhilg, H. H., Corrosion and Corrosion Control, 2nd ed., Wiley, New York, 1971.

12. Pourbaix, M., Atlas of Electrochemical Equilibria in Aqueous Solutions, Second English Edition, National Association of Corrosion Engineers, Houston, 1974. 
13. Tomashov, N. D.,: Theory of Corrosion and Protection of Metals, Translated and edited by B. H. Tytell, I. Geld, and H. S. Prefser, Macmillan, New York, 1966.

14. Hauffe, K., Oxidation of Metals, Plenum, New York, 1965. 
TABLE 1. - CORROSION RATES OF STEEL IN $\mathrm{H}_{2} \mathrm{SO}_{4}$

\begin{tabular}{|c|c|}
\hline $\begin{array}{c}\mathrm{H}_{2} \mathrm{SO}_{4} \\
\text { concentration, } \\
\text { percent }\end{array}$ & $\begin{array}{c}\text { Corrosion rate, } \\
\mathrm{mm} / \mathrm{yr}\end{array}$ \\
\hline 65 & 0.5 to 1.0 \\
75 & 0.1 to 0.5 \\
95 & 0.1 to 0.5 \\
\hline
\end{tabular}

TABLE 2. - ESTIMATED CORROSION RATES

OF WEAR AREAS OF IRON TIPS IN $\mathrm{H}_{2} \mathrm{SO}_{4}$

\begin{tabular}{|c|c|c|}
\hline \multicolumn{2}{|c|}{$\mathrm{H}_{2} \mathrm{SO}_{4}$ concentration } & $\begin{array}{c}\text { Corrosion rate, } \\
\mathrm{mm} / \mathrm{yr}\end{array}$ \\
\hline Percent & Normality & \\
\hline 0.005 & 0.001 & $\mathrm{a}<5$ \\
.05 & .01 & 7 \\
.5 & .1 & 7 \\
5 & 1 & 27 \\
30 & 7.5 & 94 \\
50 & 15 & 43 \\
65 & 21 & 25 \\
75 & 23 & 27 \\
95 & 35.6 & 57 \\
\hline
\end{tabular}

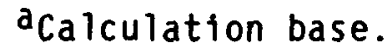




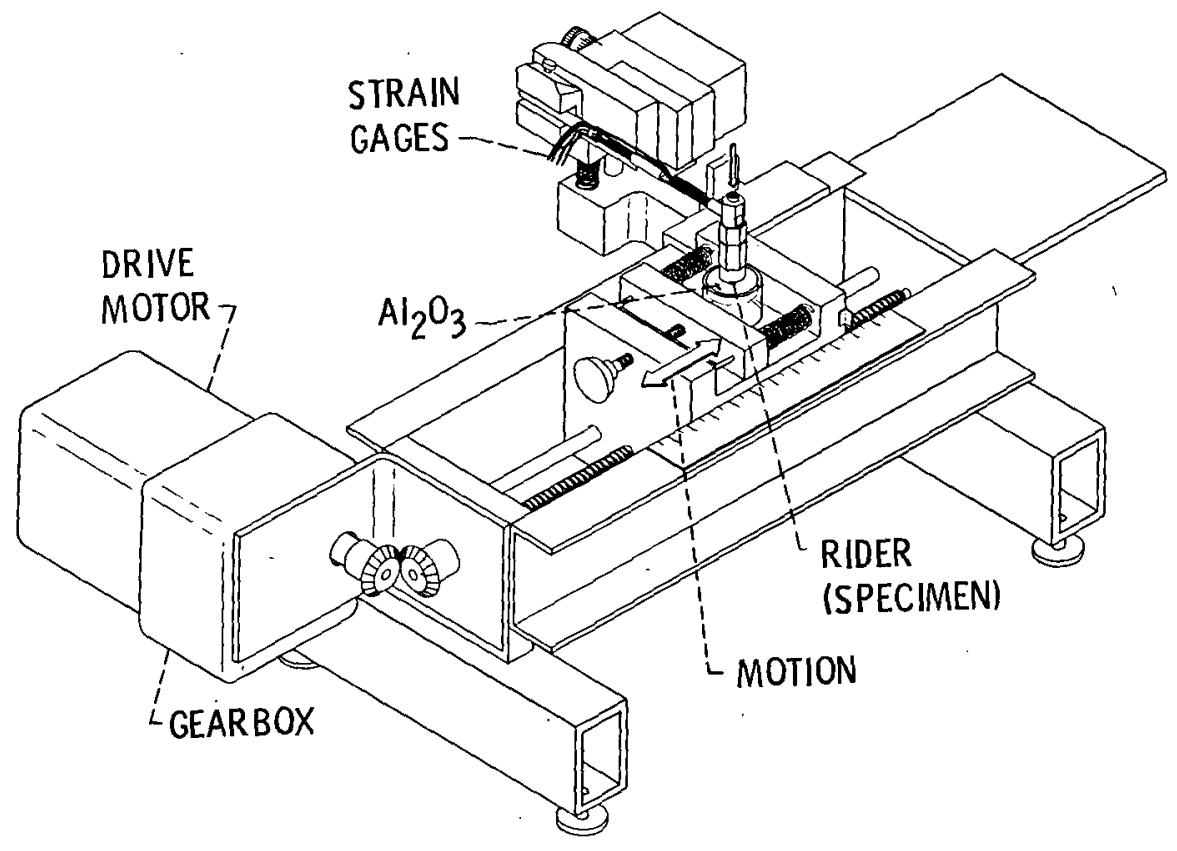

Fig. 1. - Friction and wear apparatus. 

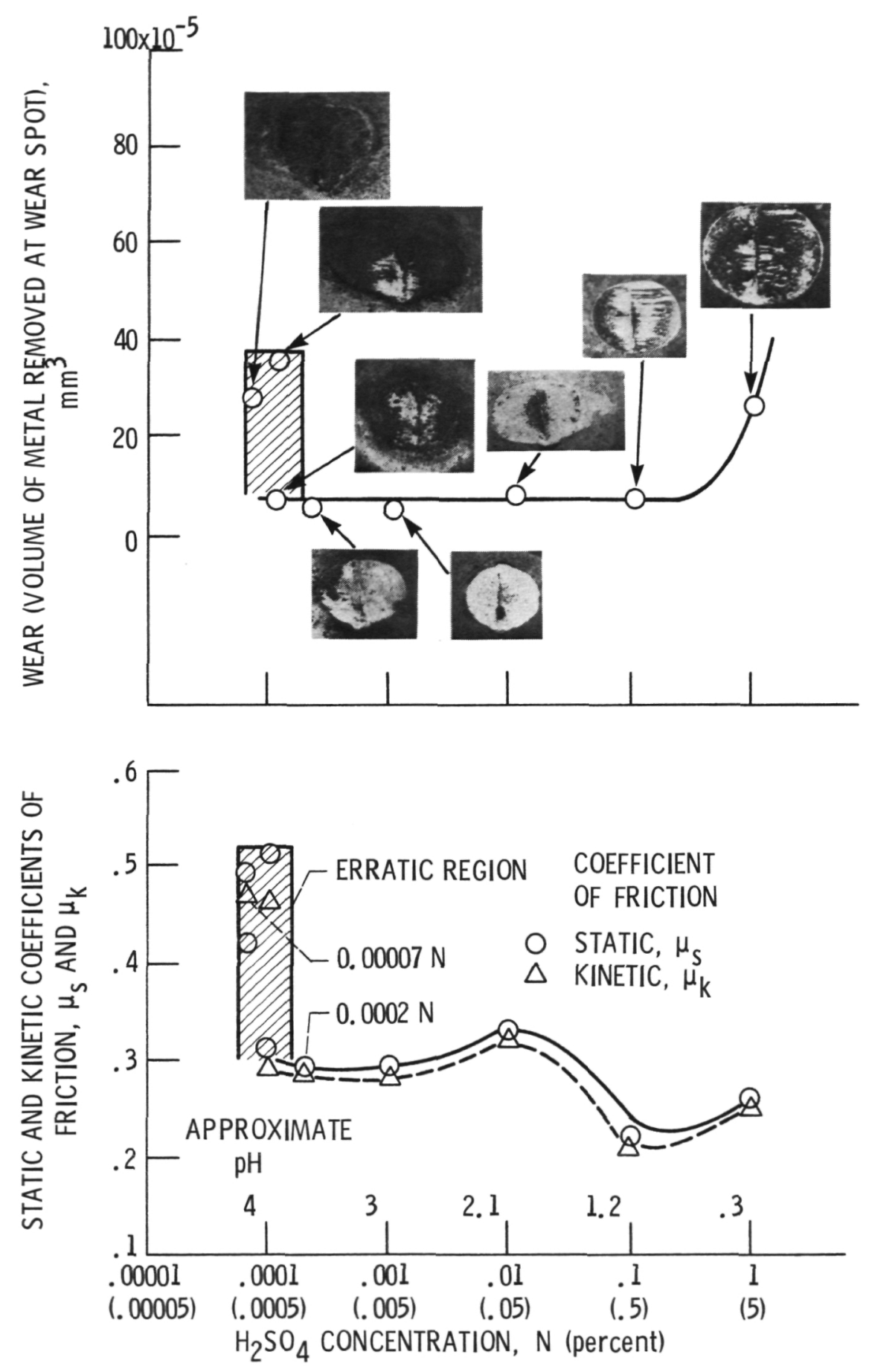

Fig. 2. - Friction and wear of iron in dilute $\mathrm{H}_{2} \mathrm{SO}_{4}$. 


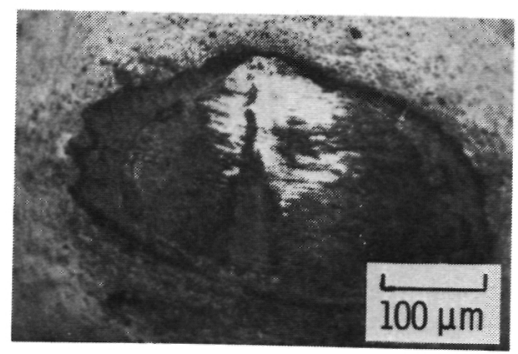

(a) Photomicrograph of wear area.

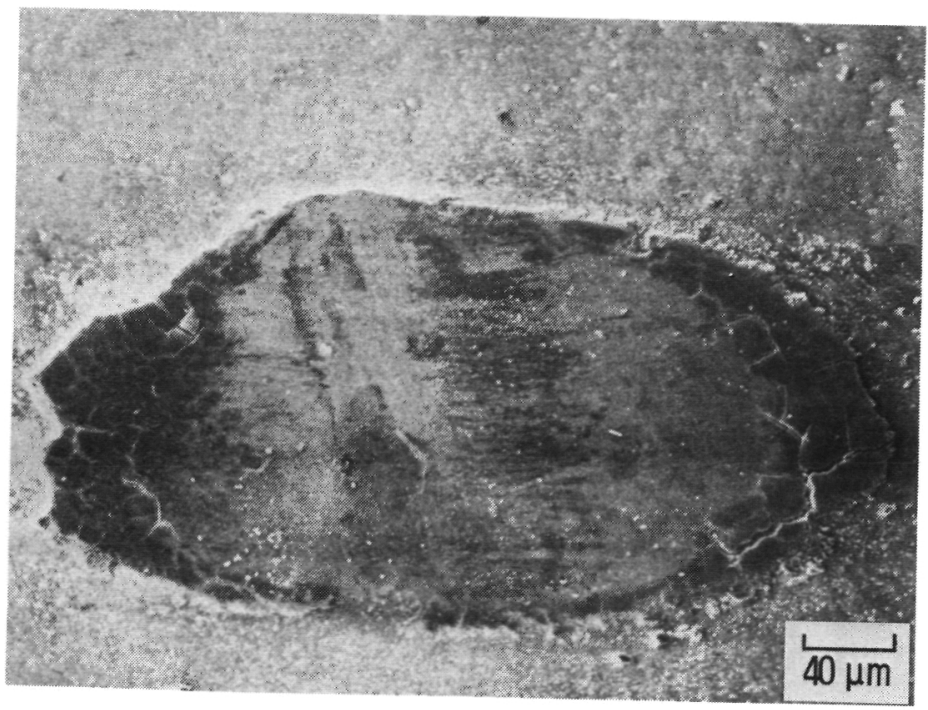

(b) SEM photograph of wear area.

Figure 3. - Wear area and surroundings - iron in $10^{-4} \mathrm{~N} \mathrm{H}_{2} \mathrm{SO}_{4}$. 


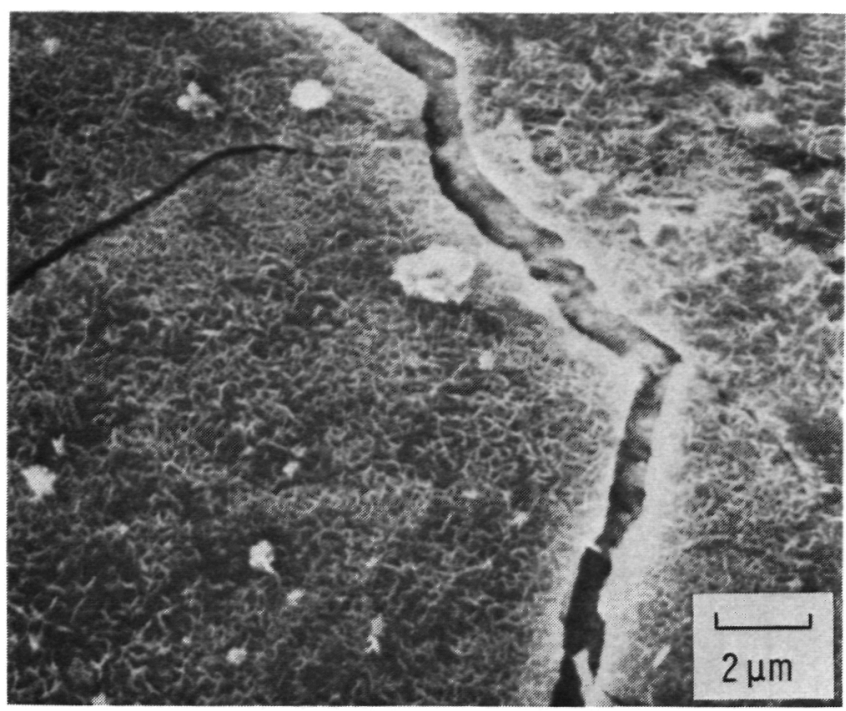

(c) SEM photograph of cracked deposit in wear area.

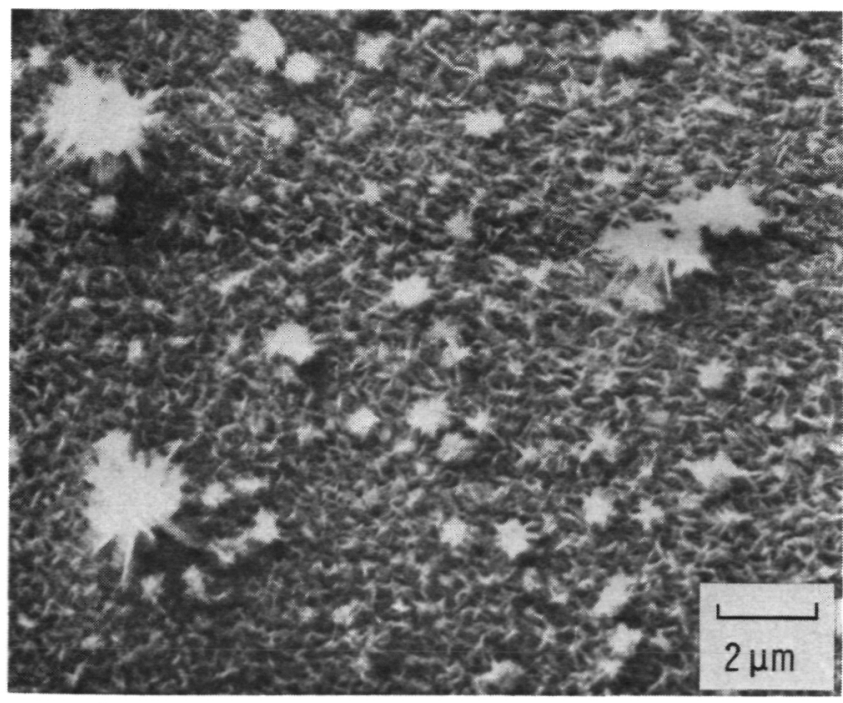

(d) SEM photograph of deposit on iron well outside wear area.

Figure 3. - Concluded. 


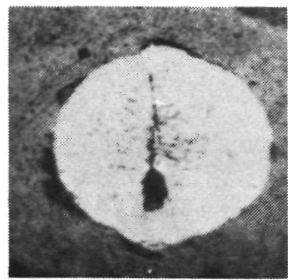

$100 \mu \mathrm{m}$

(a) Photomicrograph of wear area.

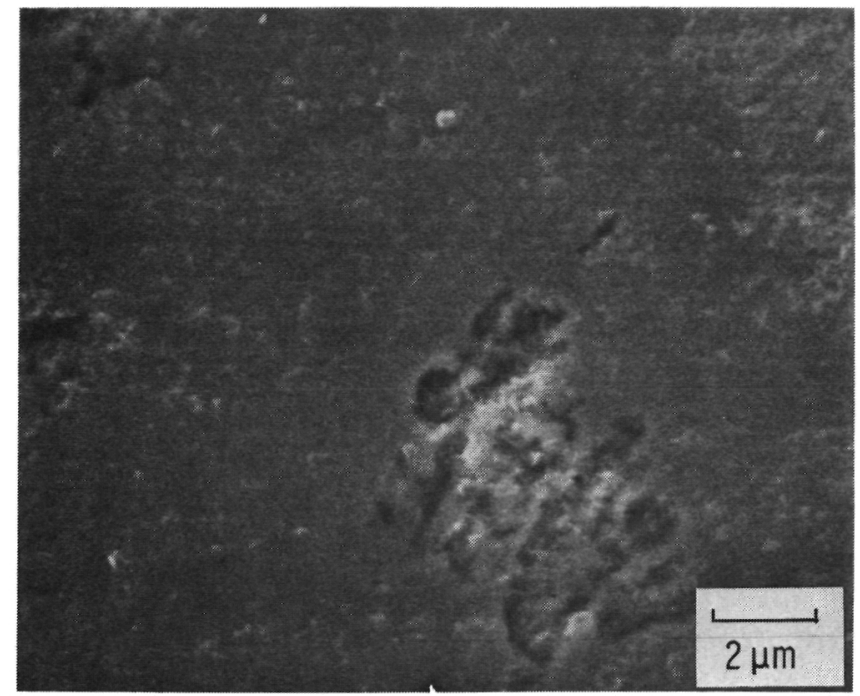

(b) SEM photograph of wear area.

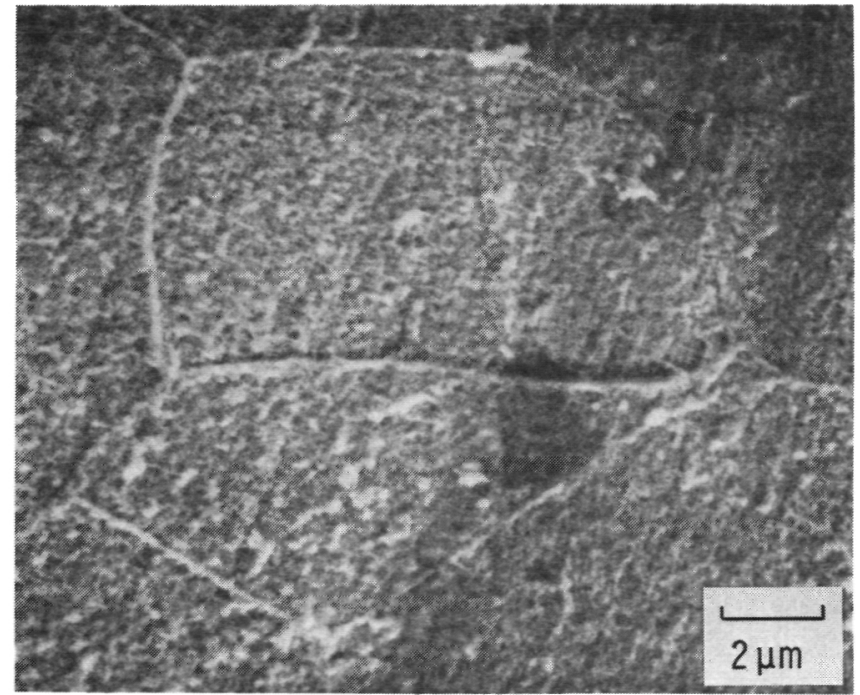

(c) SEM photograph of a lightly etched area outside wear area.

Figure 4. - Wear area and surroundings - iron in $0.001 \mathrm{~N} \mathrm{H}_{2} \mathrm{SO}_{4}$. 


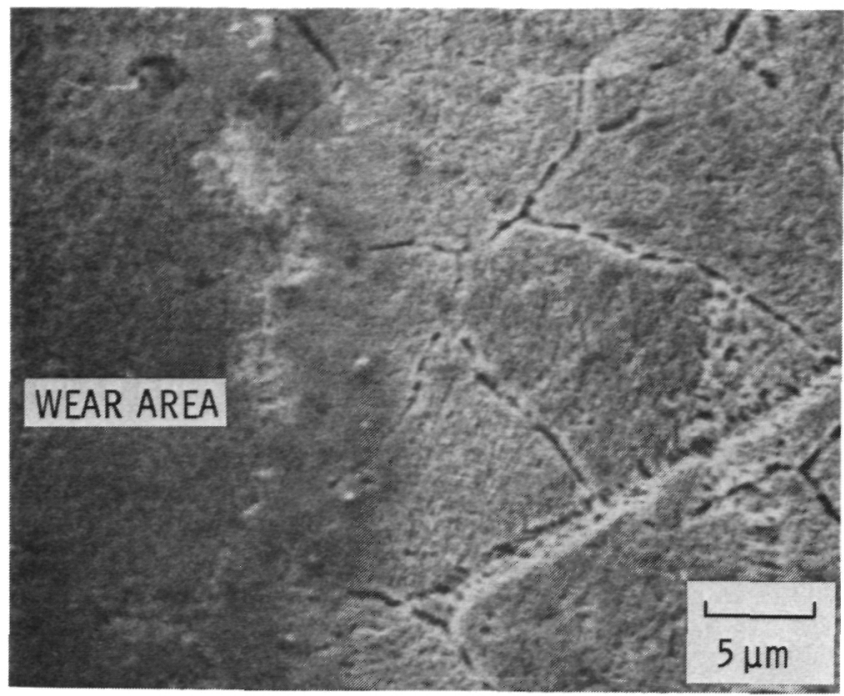

Figure 5. - SEM photograph taken at edge of wear area - iron in $1.0 \mathrm{~N}$ (5 percent) $\mathrm{H}_{2} \mathrm{SO}_{4}$.
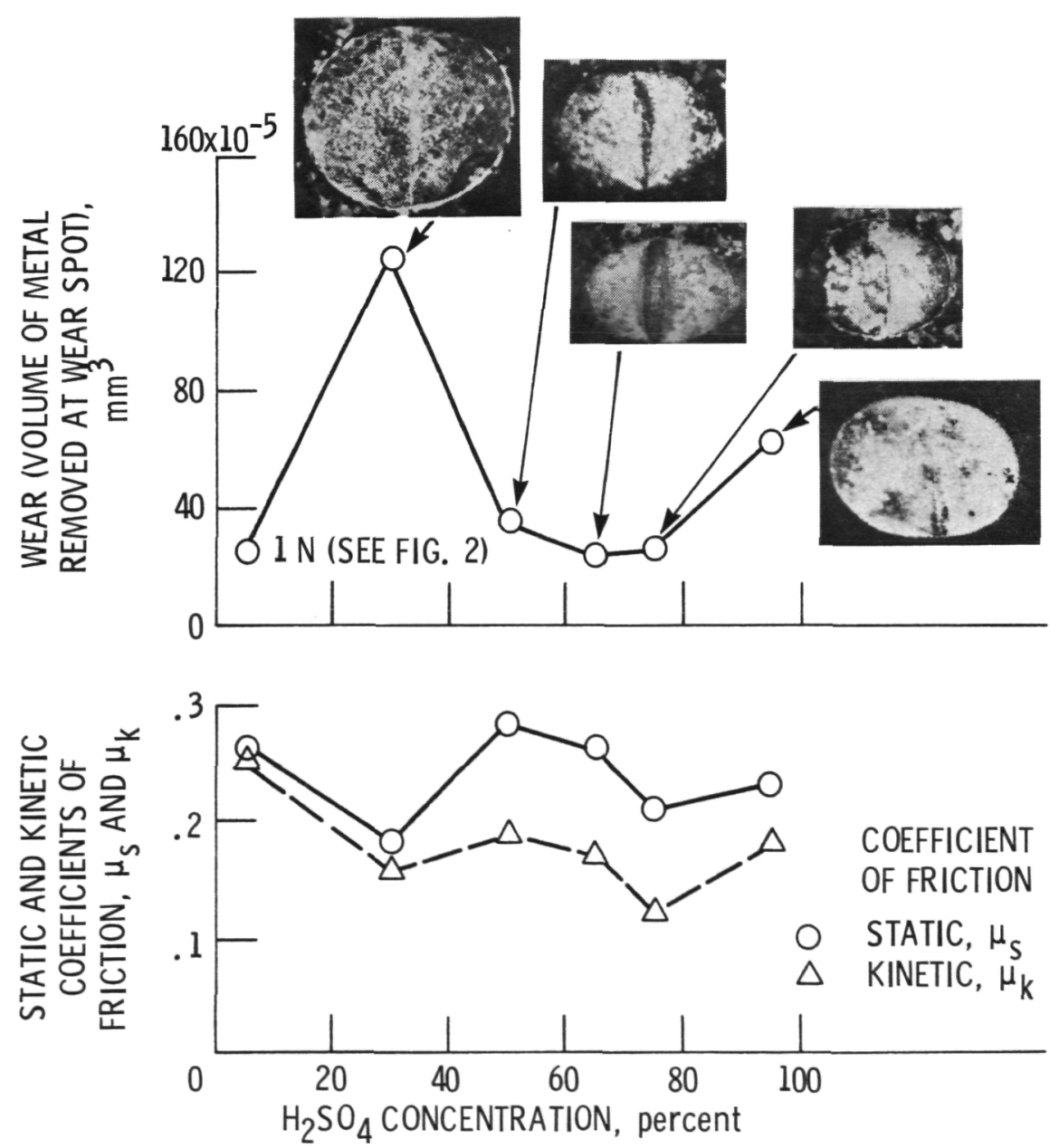

Fig. 6. - Friction and wear of iron in concentrated $\mathrm{H}_{2} \mathrm{SO}_{4}$. 


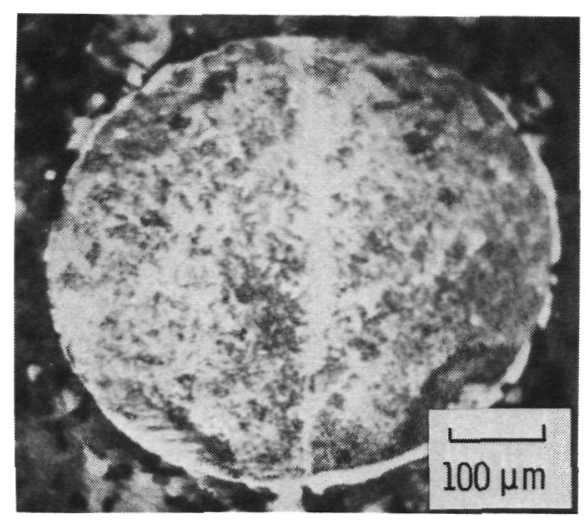

(a) Photomicrograph of wear area.

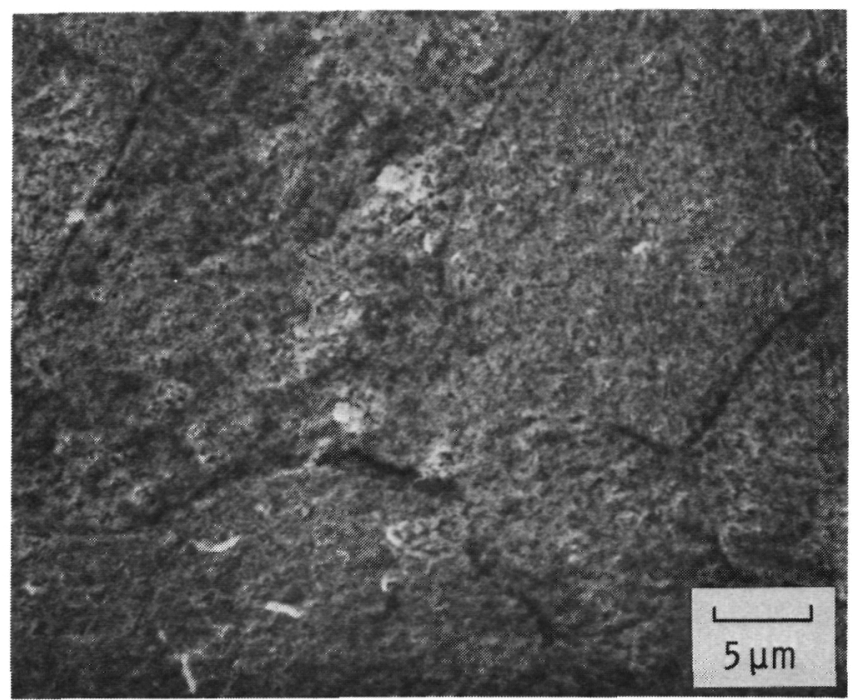

(b) SEM photograph of wear area.

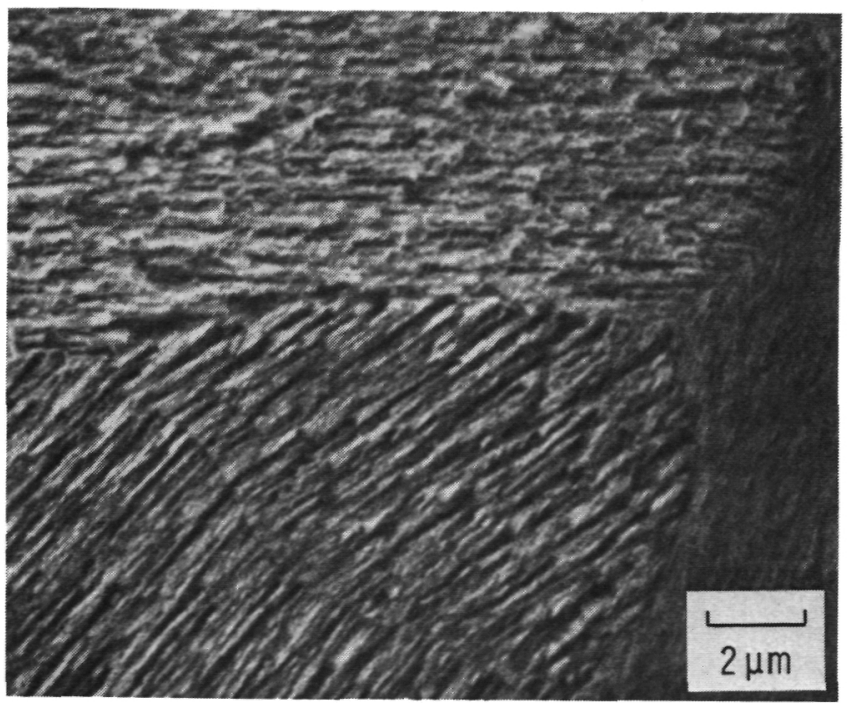

(c) SEM photograph outside wear area.

Figure 7. - Wear area and surroundings - iron in 30 percent $\mathrm{H}_{2} \mathrm{SO}_{4}$. 


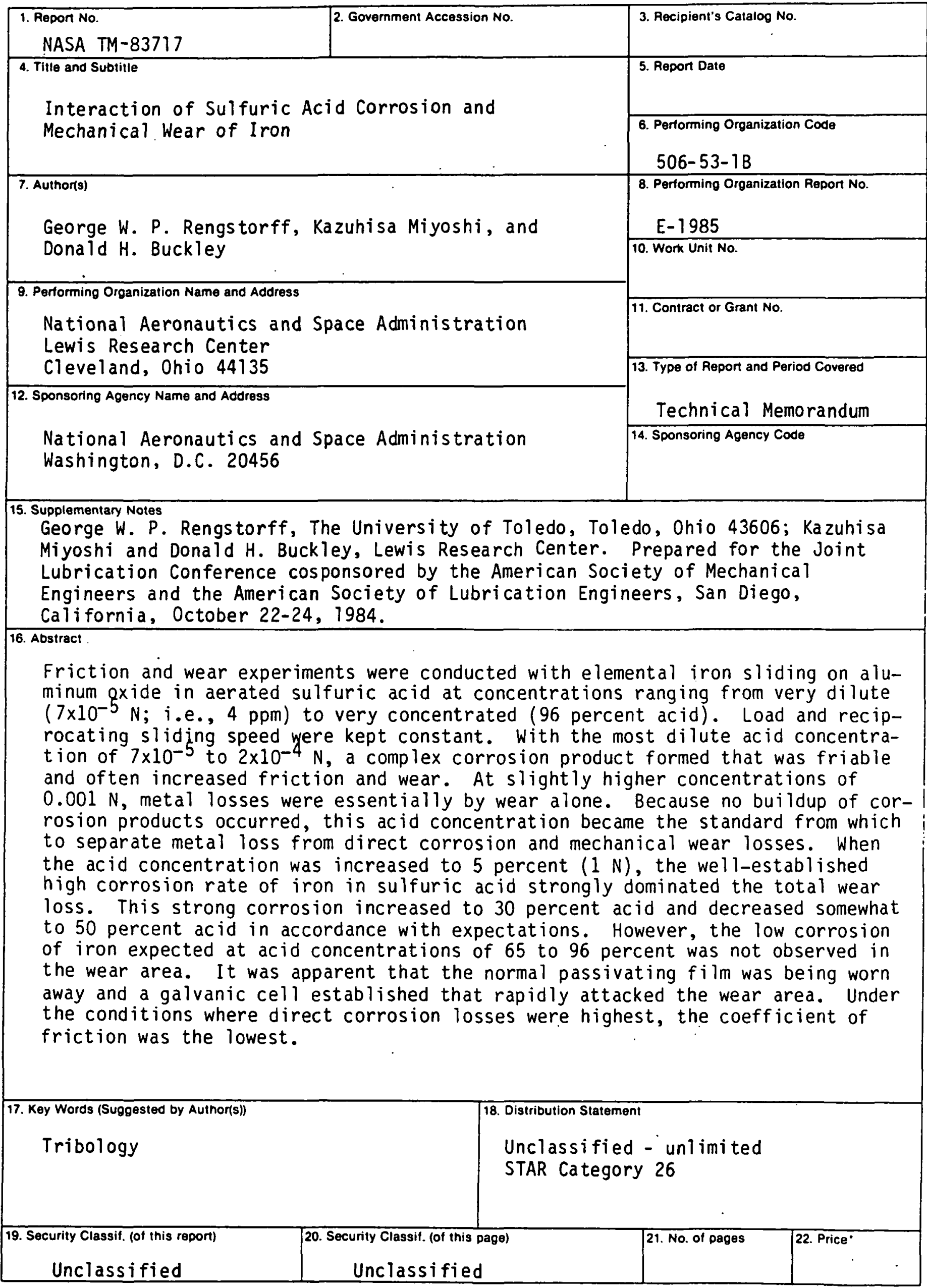

"For sale by the National Technical Information Service, Springfield, Virginia 22161 
National Aeronautics and Space Administration

Washington, D.C.

20546

Ollicial Business

Penalty for Private Use, $\mathbf{5 3 0 0}$
SPECIAL FOUATH CLASS MAIL BOOK

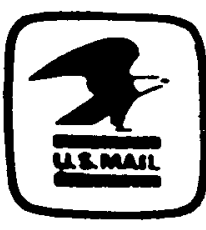

Pontege and Fees Paid

National Aeroneutics und

Spece Administration NASA-451 